\title{
Formulation of an integrated social commerce framework to promote social capital for energy sectors
}

\author{
Mohana Shanmugam ${ }^{1}$, Vinitha Karunakaran ${ }^{2}$, Asra Amidi ${ }^{3}$ \\ ${ }_{1,2}$ Department of Information Systems, College of Computing and Informatics, UNITEN, Malaysia \\ ${ }^{3}$ Department of Computer Science and Information Technology, UPM, Malaysia
}

\begin{tabular}{l}
\hline Article Info \\
\hline Article history: \\
Received Dec 13, 2018 \\
Revised Feb 25, 2019 \\
Accepted Mar 8, 2019 \\
\hline
\end{tabular}

Keywords:

Social capital

Social commerce

Social support

Theory of planned behavior

\begin{abstract}
Social capital refers to the resources available in personal and business networks. In developing a culture that values and practices social capital, social factors are considered one of the main precursors. With the proliferation of social commerce and the maturing of social media, social capital can be acquired and further developed for productive benefits, particularly for energy sectors in Malaysia. In this study, an integrated social commerce framework to promote social capital is presented and evaluated. The framework attempted to define the relationship between the Theories of Planned Behavior (TPB) and Social Support Theory (SST) alongside satisfaction and perceived value factors towards promoting social capital development in energy sectors. This research uses SPSS to analyse the data collected from employee in the energy sectors in Malaysia. Research reveals that social capital is present when there is trust and loyalty among the users and the significance of social capital is monumental for energy sectors' productivity, efficiency and profitability. A survey is adapted and distributed to 20 respondents from the energy sector in Malaysia as a mean to study on the validity and reliability of the research factors. Results indicate that all proposed factors are significant in promoting social capital except one, which is the Perceived Behavioral Control (PBC) of the TPB.
\end{abstract}

Copyright $@ 2019$ Institute of Advanced Engineering and Science. All rights reserved.

\author{
Corresponding Author: \\ Mohana Shanmugam, \\ Department of Information Systems, \\ Universiti Tenaga Nasional (UNITEN), \\ Jalan Ikram-Uniten, Institut Latihan Sultan Ahmad Shah, \\ 43000 Kajang, Selangor, Malaysia. \\ Email: Mohana@uniten.edu.my
}

\section{INTRODUCTION}

The notion of social capital first emerged from social relations [1] with a range of potential benefits including facilitation of higher levels of growth in gross domestic products, facilitation of more efficient functioning of labor markets and improvements in the effectiveness of institutions of government [2-5]. With the recent emergence of globalization and social commerce era, the economic and business performance are affected by social capital and focuses more on the participation of users in a social commerce context. Literature has reported that the intervention of social capital makes a company an effective network by bridging and bonding cultures social influences with the aim on knowledge exchange communication [6] to promote social capital.

There is a wide range of online platforms and technologies that can be utilized to support social capital in industries, particularly the energy sectors. Evidence show that social capital theory suffers from much criticism for being poorly defined and conceptualized [7]. It is also unclear to which extend social commerce, a prominent cursor to social relations assist in promoting social capital for productive benefits. In order to optimize the gains from social capital, it is central to investigate and apply social related 
constructs to empower the growth of social capital in an industry such as the energy sectors. In fact, recent research on knowledge-based urban development for emerging economies like Malaysia is being undertaken and emphasized for prosperous development [8] in which social capital is prioritized.

In an energy sector, social capital needs to be accentuated for producing good results in the implementation of energy efficiency policy [9]. Simply put, social capital is not simply the sum of institutions which underpin a society but more of the glue that holds them together. Evidence also show though there are many studies on energy sectors with regards to energy consumption and social capital, there do not appear to be any that empirically attempt to directly examine a link between them [10]. Although a study associating both social support and social capital in an online community context affirmed the benefits of social support in fostering the creation and maintenance of social support, no theories or models emerged as a novel finding of this research [11]. It is therefore necessary to exploit and develop components necessary for the accumulation of social capital from a social commerce perspective for the importance of societal wellbeing, particularly in energy sectors.

\section{LITERATURE REVIEW}

\subsection{Social Capital}

Social capital theory comes from sociological and political discussion around the formation and survival of communities communities [12]. Recently social capital theory have been used in many domains such as management, economics, and the design of IT [13]. Putnam defines social capital as the value of social committee such as network, norms and trust that build up coordination and cooperation to achieve goals [14]. Social capital is also stated as a multidimensional theory that consists of few factors such as trust, loyalty, information support, emotional support [15] and cooperation [16]. In this study, social capital is discussed using three factors which are trust, loyalty and cooperation.

Trust plays an important role in social capital where it increases individuals intuition to interact with others and show off their best behavior [17]. Trust is defined as an understanding between individuals or groups that are known as trustor and trustee where trustor will evaluate decisions based on a trustee's behavior [18]. Trust is also known as a common mechanism for reducing community problems and risk of transaction by increasing the positive expectation of trustee [19]. The level of trust among individuals can be observed from the impact on the value of any transaction [20]. Therefore, as the level of trust placed by individuals increase the social capital level becomes higher.

Loyalty is considered as a feeling, affection or opinion of people towards other people, products or services [21]. From the definition, we can conclude that when a person is buying from the similar firm several times, loyalty is present. Past research states that loyalty is present among individuals if the product or services meets user requirements and satisfaction [22]. Trust, emotion and also affection are the important components that are needed to build true loyalty [23]. People's loyalty is strongly predicted by the trust that they have on the products and services. In this study, loyalty can be observed from the continuance use of social networking sites.

Cooperation on the other hand involves a group of people that have a strong relationship to work together [24]. To build a strong relationship among the people in a group or in an organization, mutual trust, respect and friendship is needed [25-26]. According to Fukuyama, social capital is related to cooperation between two or more individuals [27]. Past research has reported that the presence of social capital will improve efficiency by enabling cooperation among individuals [27]. In this study, cooperation between employees in energy sector is believed to increase the productivity and efficiency.

\section{RESEARCH MODEL AND HYPOTHESIS DEVELOPMENT}

\subsection{Theories of Planned Behavior}

Theory of planned behavior (TPB) is an extension of Theory of reasoned action (TRA) [28]. The difference between TPB and TRA is in the presence of perceived behavioral control [29]. The formation of TPB is to examine and differentiate between behavioral intention and actual behavioral [30]. TPB is a multidimensional factor that consists of attitude (ATT), subjective norms (SN) and perceived behavioral control (PBC) [26]. These three factors are merged together in predicting human intentions and behavior [31].

Attitude refers to a person's feelings, thinking or action that they show in involving and performing a task or situation [32]. Past research states that attitude exists in two levels which are explicit level and implicit level that effect individual's behavior [33]. Explicit level is considered as a level that can still be controlled while implicit level is the level that cannot be controlled [34]. In this study, attitude is related to 
the social network community's behavior on using social network sites. Past research has proven that attitude positively influences behavioral intention [30].

Perceived behavioral control is defined as perceived ease or can be stated as a difficulty on performing behavior [35]. Based on past research, it is stated that perceived behavioral control is a concept based on experiences, individual's opinion and second hand information [30]. Past research has also reported that perceived behavioral control directly influences behavioral intention [28, 30]. Thus, there is a positive bonding between perceived behavioral control and behavioral intention.

Subjective norms is known as a social pressure from group of individuals to decide whether to act or not to act upon an action [36]. Subjective norms is known to be an important variable than attitude, where it is important to create interruption activities that would change perceive norms based on the problems [35]. Previous research has reported that subjective norms positively influences behavioral intention [30]. This study therefore proposes the following hypotheses:

H1. User's attitude influences behavioral intention

H2. User's perceived behavioral control influences behavioral intention

H3. User's subjective norms influences behavioral intention

\subsection{Satisfaction}

Satisfaction can be defined as people's behavior and feelings towards products, services or activities [37]. In this research, satisfaction refers to loyalty of online community on using their favourite networking sites. The loyalty from online communities can be achieved by having accurate and protected information that increases their trust level. The satisfaction level is increased if the level of loyalty is higher [38], while loyalty can be achieved from individuals by meeting all their requirements and needs [26]. Previous study has proven that satisfaction positively influences perceived value [26]. Therefore, a positive relationship between satisfaction and perceived value for individuals using social networking is hypothesized as follow:

H4. User's satisfaction influences perceived value.

\subsection{Perceived Value}

Perceived value is defined as the overall assessment of goods and advantages associated with products and services [39]. Past research has stated that perceived value can be obtained from four factors namely economic, functional, emotional and social utility [40]. Moreover, according to [41-42], perceived value can also be considered as a factor to build long-term relationship within customer and industry. In this study, perceived value is present when online communities evaluate the benefits and quality from using social networking sites to gain trust and show loyalty in using their favorites networking sites. Furthermore, gaining of trust and loyalty from social communities directly give a positive impact on social capital. Previous research also affirms that perceived value positively influences social capital [39]. The following hypothesis is therefore formulated:

H5. User's perceived value drives social support

\subsection{Social Support}

Social support refers to individual's feelings when they are being loved, cared for and helped by others [43]. Social support is always intent to be positive and helpful where it avoids from negative intention and interaction [44]. In this study, social support refers to the feelings of online communities when they get solution for their problems. People nowadays use social networking sites to share their knowledge, emotion and experience [44]. Past research has reported that social support is categorized into three factors: emotional support, tangible support and informational support [45]. For the purpose of this study, the emotional and informational support is deem appropriate due to the nature of online communities.

Emotional support refers to an attachment among individuals that show feelings such as love, care and respects for each other [44]. Presence of emotional support among individuals reduces stress level [46]. In this study, emotional support is related to the opinion or feelings that people show to each other in social networking sites. This support makes people gain trust from social communities where they feel secure in sharing their emotion through social networking sites [30].

Informational support is related to the involvement of data, information and knowledge that are shared among individuals for a better decision making [47]. Understanding of emotion will improve the relationship among individuals and provide active support [44]. According to [48] information, particularly factual evaluation information, posted in response by members might help to solve problems. In this study, 
informational support is present when online communities share their information and knowledge in social networking sites where they have a high level of trust towards social networking sites. There is also evidence that social support positively influences social capital by building trust and loyalty among users [49]. Consequently, the following hypotheses are formulated:

H6. User's social support drives behavioral intentions

H7. User's social support drives social capital

\subsection{Behavioral Intention}

Behavioral intention is defined as a user's opinion to react upon a specific action [26]. It is also known as an individual's perception on acting towards their favorable or unfavorable action [32]. Past research has reported that perceived value is used to predict the actual behavior [36]. In this study, behavioral intentions refer to online communities' intention to continue using their favourite social networking sites in future. The intention increases if the level of trust towards the social networking sites increases [36] thus promoting social capital. Therefore, the following hypothesis is populated. Research model as shown in Figure 1.

H8. Behavioral intentions of users drive social capital

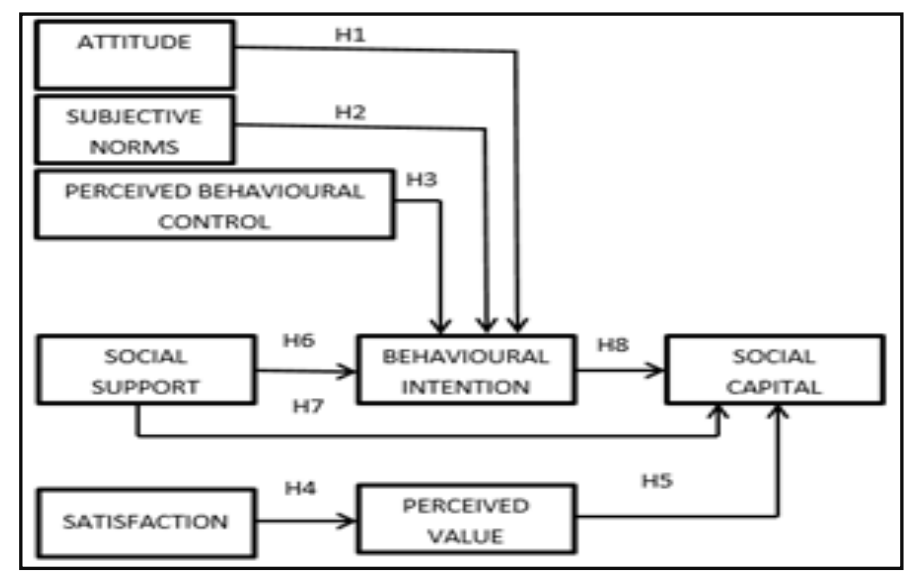

Figure 1. Research model

\section{RESEARCH METHODOLOGY}

An online survey was conducted using questionnaire as the main data collection instrument. The questionnaire design was based on prior literature [50] adapted accordingly to suit this study. To validate the survey instruments, 5 respondents were engaged. This phase of study validated the face validity and content validity of the instrument. Based on the feedbacks and comments during this phase, the questionnaire items were modified to ensure that the purpose of the study is made clear and appropriately validated. Subsequently, a pilot test was run with 20 respondents to assess the reliability of the questionnaire items. The questionnaire survey used ordinal scale for demographic data collection and interval scale (7-point Likert) for remaining data collection. The details of the respondents' demographic are as shown in Table 1.

\section{PRELIMINARY RESULTS}

The number of indicators for the initial instrument is as shown in Table 2. The Indicator Reliability for Indicator Loadings is as presented in Table 3. These indicator loadings measure how much of the indicators variance are explained by the corresponding latent construct. All loadings except for three items $\mathrm{PBC} 1, \mathrm{PBC} 2$ and PBC3 is reported low and therefore is dropped for the actual study.

The study model was assessed using SPSS. The model was first evaluated in terms of reliability. Reliability was evaluated using the composite reliability. As shown in Table 4, the composite reliability of the seven latent variables is all larger than 0.70 which indicates an acceptable level and ideal internal quality of a model for exploratory research except for one variable which is lesser than 0.70 which indicates a poor internal consistency. 
Table 1. Demographic Details of the Respondents

\begin{tabular}{lccc}
\hline Demographic & Group & Frequency & Percentage $(\%)$ \\
\hline Gender & Male & 12 & 60.0 \\
Profession & Female & 8 & 40.0 \\
& Intern student & 5 & 25.0 \\
& Professional & 8 & 40.0 \\
Member of social networking sites & Executive & 5 & 25.0 \\
& Other & 2 & 10.0 \\
Social networking sites used & Yes & 20 & 100 \\
& No & 0 & 0 \\
& Facebook & 9 & 45.0 \\
& LinkedIn & 0 & 0 \\
Social networking sites usage experience & Twitter & 3 & 15.0 \\
& Google+ & 4 & 20.0 \\
& Other & & 0 \\
& Less than 1 & 0 & \\
& year & & 5.0 \\
& 1 - 2 years & 1 & 20.0 \\
& 2 - 3 years & 4 & 20.0 \\
& 3 - 4 years & 4 & 55.0 \\
\hline
\end{tabular}

Table 2. Number of Indicators for Initial Instrument

\begin{tabular}{lc}
\hline Constructs & Number of indicators \\
\hline Social support (SS) & 7 \\
Satisfaction (SAT) & 3 \\
Attitude (ATT) & 3 \\
Perceived behavioral control (PBC) & 3 \\
Subjective norms (SN) & 2 \\
Perceived value (PV) & 3 \\
Continuance participation intention (CPI) & 3 \\
Social capital (SC) & 4 \\
\hline
\end{tabular}

Table 3. Analysis of Reliability for Pilot Study

\begin{tabular}{|c|c|c|c|c|c|}
\hline Factors & Item & $\begin{array}{c}\text { Scale mean if item } \\
\text { deleted }\end{array}$ & $\begin{array}{l}\text { Scale variance if } \\
\text { item deleted }\end{array}$ & $\begin{array}{c}\text { Corrected item-total } \\
\text { correlation }\end{array}$ & $\begin{array}{c}\text { CA if item } \\
\text { deleted }\end{array}$ \\
\hline \multirow[t]{7}{*}{ SS } & SS1 & 33.24 & 68.090 & 0.955 & 0.955 \\
\hline & $\mathrm{SS} 2$ & 33.38 & 68.348 & 0.865 & 0.963 \\
\hline & SS3 & 32.90 & 73.890 & 0.917 & 0.961 \\
\hline & SS4 & 33.19 & 68.662 & 0.883 & 0.961 \\
\hline & SS5 & 32.95 & 71.648 & 0.928 & 0.959 \\
\hline & SS6 & 33.05 & 69.548 & 0.913 & 0.959 \\
\hline & SS7 & 33.29 & 69.214 & 0.770 & 0.971 \\
\hline \multirow[t]{3}{*}{ SAT } & SAT1 & 4.38 & 4.948 & 0.913 & 0.930 \\
\hline & SAT2 & 4.48 & 5.562 & 0.948 & 0.908 \\
\hline & SAT3 & 4.10 & 5.390 & 0.863 & 0.965 \\
\hline \multirow[t]{3}{*}{ ATT } & ATT1 & 11.76 & 3.790 & 0.785 & 0.935 \\
\hline & ATT2 & 11.81 & 3.962 & 0.895 & 0.851 \\
\hline & ATT3 & 11.86 & 3.629 & 0.854 & 0.877 \\
\hline \multirow[t]{3}{*}{ PBC } & PBC1 & 8.57 & 2.957 & 0.401 & 0.605 \\
\hline & PBC2 & 6.24 & 6.790 & 0.086 & 0.482 \\
\hline & PBC3 & 9.86 & 3.729 & 0.114 & 0.240 \\
\hline \multirow[t]{2}{*}{ SN } & SN1 & 5.81 & 1.262 & 0.576 & \\
\hline & SN2 & 5.33 & 2.233 & 0.576 & \\
\hline \multirow[t]{3}{*}{ PV } & PV1 & 11.90 & 3.490 & 0.934 & 0.914 \\
\hline & PV2 & 11.81 & 4.362 & 0.930 & 0.910 \\
\hline & PV3 & 11.81 & 4.562 & 0.861 & 0.958 \\
\hline \multirow[t]{3}{*}{ CPI } & CPB1 & 11.86 & 5.129 & 0.844 & 0.975 \\
\hline & CPB2 & 12.05 & 4.048 & 0.907 & 0.939 \\
\hline & CPB3 & 11.90 & 4.590 & 0.979 & 0.878 \\
\hline \multirow[t]{4}{*}{ SC } & $\mathrm{SC} 1$ & 16.86 & 12.629 & 0.898 & 0.941 \\
\hline & $\mathrm{SC} 2$ & 17.14 & 11.529 & 0.892 & 0.943 \\
\hline & SC3 & 17.19 & 11.562 & 0.923 & 0.932 \\
\hline & SC4 & 16.95 & 12.948 & 0.866 & 0.950 \\
\hline
\end{tabular}

*Cronbach’s Alpha (CA) 


\begin{tabular}{ccc}
\multicolumn{3}{c}{ Table 4. Summary for Reliability for Pilot Study } \\
\hline Factors & CA & Summary \\
\hline SS & 0.967 & Very good internal consistency \\
SAT & 0.955 & Very good internal consistency \\
ATT & 0.922 & Very good internal consistency \\
PBC & 0.244 & Poor internal consistency. Drop it. \\
SN & 0.712 & Acceptable \\
PV & 0.952 & Very good internal consistency \\
CPI & 0.954 & Very good internal consistency \\
SC & 0.956 & Very good internal consistency \\
\hline
\end{tabular}

\section{CONCLUSIONS AND FUTURE WORK}

In the social commerce era, individuals are increasingly using online communities. This study examines the constructs that drive social capital in energy sectors, Malaysia through social networking communities. To achieve its aims, this study extends the standard Theory of Planned Behavior by including social support constructs; namely the informational and emotional constructs alongside with the perceived value and satisfaction construct in promoting social capital. The main purpose of this paper is to highlight the importance of social capital in the growth process of energy sector. Results show that all proposed factors of the study have acceptable and good internal consistency except for PBC from TPB. We can also conclude that when the employee's ability to share and cooperate is high, the employee's output also increases, resulting in higher energy sector's productivity.

Future study will look into testing the proposed research model with a wider target audience from the energy sector. Data gathered from the future study will be analysed using the Partial Least Squares (PLS) of the Structural Equation Modeling (SEM).

\section{REFERENCES}

[1] Lin, N., Y. Fu, and R. Hsung, "Position Generator: A Measuremet for Social Capital”. Social Capital: Theory and Research, 2001: p. 51-87.

[2] Aldridge, et al., "Social Capital: A Discussion Paper". Perfomance and Innovation Unit, 2002.

[3] Halpern, D., "Moral values, social trust and inequality: can values explain crime?", British Journal of Criminology, 2001.

[4] Kawachi, et al., "Social Capital and Self-Rated Health: A Contextual Analysis", American Journal of Public Health, 1999. 89: p. 1187-1193.

[5] Putnam, R., "The Prosperous Community: Social Capital and Public Life". The American Prospect, 1993. 4.

[6] Bouzdine, T. and M. Bourakova, "The Role of Social Capital within Business Networks: Analysis of Structural and Relational Arguments". Fifth European Conference on Organisational Knowledge, Learning and Capabilities, 2004.

[7] Hean, et al., "The M-C-M Cycle and Social Capital". Social Science Medicine, 2003. 56: p. 1061-72.

[8] Yigitcanlar, T. and M. Sarimin, "Multimedia Super Corridor, Malaysia: Knowledge-Based Urban Development Lessons from An Emerging Economy”. Journal of Information and Knowledge, 2015. 45(1): p. 126-147.

[9] Djourdjin, M. and A. Yotova, "Social Capital for Energy Efficiency: the Need of Partnership For Policy Integration and Implementation in the Case of Bulgaria". Berlin Conference on the Human Dimensions of Global Environmental Change "Greening of Policies - Interlinkages and Policy Integration", 2004.

[10] McMichael, M., "A Social Capital Approach to Household Energy Consumption". Dynamics of Consumption, 2007. 9: p. 1897-1905.

[11] Drentea, P. and L. Jennifer, "Social Capital and Social Support on the Web: the Case of An Internet Mother Site". Sociology of Health and Illness, 2005. 27(7): p. 920-943.

[12] Gleasure, R.a.M., L., "The Pastoral Crowd: Exploring Self-Hosted Crowdfunding using Activity Theory and Social Capital". Journal of Information Systems, 2017. 28: p. 489-515.

[13] Yang, S., H. Lee, and S. Kurnia, "Social Capital in Information and Communications Technology Research: Past, Present, and Future". Communications of the Association for Information Systems, 2009. 25(23): p. 183-220.

[14] Putnam, R.D., "Bowling Alone: America's Declining Social Capital”. Journal of democracy, 1995. 6(1): pp. 223-234.

[15] Cho, J.H., I. Alsmadi, and D. Xu, "Privacy and Social Capital in Online Social Network", in 2016 IEEE Global Communication Conference (GLOBECOM). 2017, IEEE: Washington, DC, USA.

[16] Teng, C.I., "Managing Gamer Relationship to Enhance Online Gamer Loyalty: the Perspective of Social Capital Theory and Self-Perception Theory". Managing Gamer Relationship to Enhance Online Gamer Loyalty: the Perspective of Social Capital Theory and Self-Perception Theory, 2017. 79: p. 59-67.

[17] Wu, I.L. and M.L. Chiu, "Examining Supply Chain Collaboration with Determinants and Performance Impact: Social Capital, Justice and Technology Use Perspectives". Internation Journal of Information Management, 2018. 39: pp. 5-19. 
[18] Cho, J.H. and K.S. Chan, "A Survey on Trust Modelling ACM Computing Survey". ACM Conference on Electronic Commerce 2015. 48(2): p. 28.

[19] Wu, I.L. and J.L. Chen, "An Extension of Trust and TAM Model with TPB in Initial Adoption of On-Line Tax: An Empirical Study”. International Journal of Human-Computer Studies, 2005. 62: p. 784-808.

[20] Gupta, A., K. Raman, and C. Shang, "Social Capital and the Cost of Equity Journal of Banking and Finance", 2017. 87: p. 102-117.

[21] Xu, F. and J.T. Du, "Factor Influencing User's Satisfaction and Loyalty to Digital Libraries in Chinese Unversities". Computer in Human Behavior, 2018. 83: p. 64-72.

[22] Silva, F.J.C., M.A.R. Camacho, and M.V. Vaazque, "The Tourist Index: A New Indicator for Measuring Tourist Destination Loyalty?", Journal of innovation and knowledge, 2017. 66: p. 9.

[23] Tanford, S., "The Impact of Tier Level on Attitudinal Behavioral Loyalty of Hotel Reward Program Members". International journal of hospitality management, 2013. 34: p. 285-294.

[24] Weber, B. and Heidenreich., "When and Whit Whom to Coorperate? Investigating Effects of Cooperation Stage and Type of Innovation Capabilities and Success", Long Range Planning, 2018. 51(2): p. 334-350.

[25] Sozbilir, F., The Interaction Between Social Capital, Creativity and Efficiency in Organizations". Thinking Skills and Creativity, 2018. 27: p. 92-100.

[26] Shanmugam, M., et al., "Measuring Continuance Participation in Online Communities". Journal of Theoretical and Applied Information Technology, 2015. 95(15).

[27] Fukuyama., "Social Capital, Civil Society and Development". Third World Quaterly, 2001. 22(1): p. 7-20.

[28] Ajzen, I., "The Theory of Planned Behavior". Organization Behavior and Human Decision Processes, 1991. 50: pp. 179-211.

[29] Chang, M.K., "Predicting Unethical Behavior: A Comparison of the Theory of Reasoned Action and the Theory of Planned Behavior". Journal of Business Ethics, 1998. 17: p. 1825-1834.

[30] Hajli., et al., "A Study on the Continuance Participation in On-Line Communities with Social Commerce Perspective". Journal of Technological Forecasting and Social Change, 2015. 96: p. 232-241.

[31] Brown and V. Venkatesh, "Model of Adoption of Technology in Households: A Baseline Model Test and Extension Incorporating Household Life Cycle". MIS Quarterly, 2005. 29(3): p. 399-426.

[32] Ajzen, I. and M. Fishbein, "Understanding Attitudes and Predicting Social Behavior”. Vol. 24. 1980: Prentice-Hall, Englewood Cliffs, NJ.

[33] Blair, V., N. Dasgupta, and J. Glaser, "Implicit Attitudes Handbook of Personality and Social Psychology, Attitudes and Social Cognition American Psychological Association", 2015. 1: p. 665-691.

[34] Ledesma, R.D., et al., "Predicting Road Safety Behavior with Implicit Attitude and the Theory of Planned Behavior". Journal of Safety Research, 2018. 66: p. 187-194.

[35] Jenmott III, J.B., et al., "The Theory of Planned Behavior As A Model of Intention for Fighting Among African American and Latino Andolescent". Martenal and Child Journal, 2001. 5(4): p. 253-263.

[36] Hsu, "The Management of Sports Tourism: A Causal Modeling Test of the Theory of Planned Behaviour". International Journal of Management, 2013. 30(2): p. 474-491.

[37] Chen, M.H., H.Y. Wan, and M.C. Wang, "Knowledge Sharing, Social Capital, and Financial Performance: the Perspective of Innovation Strategy in Technology Cluster". Knowledge Management Research and Practice, 2018. 16(1): p. 89-104.

[38] Shankar, V., A.K. Smith, and A. Rangaswamy, "Customer Satisfaction and Loyalty in Online and Offline Environments". Internatuinal Journal of Research and Marketing, 2003. 20: p. 153-175.

[39] Yuen, K.F., et al., The Effect of Sustainable Shipping Practices on Shippers' Loyalty: the Mediating Role of Perceived Value, Trust and Transaction Cost. 2018. 116: p. 123-135.

[40] Grace. and L. Lacono, "Value Creation: An Internal Customers' Perspective". 2015. 29(6): p. 560-570.

[41] Cronin., "Assesing the Effects of Quality, Value and Customer Satisfaction on Consumer Behavioral Intentions in Service Environments". Journal of Retailing, 2000. 76(2): p. 193-218.

[42] Parasuraman, A. and D. Grewal, "The Impact of Technology on the Quality-Value-Loyalty Chain : A Research Agenda". Journal of the Academy of Marketing Science, 2000. 28(1): p. 168.

[43] Crocker, J. and A. Canevello, "Creating and Undermining Social Support in Communal Relationships: The Role of Compassionate and Self-Image Goals”. Journal of Personality \& Social Psychology, 2008. 95(3): p. 555-575.

[44] Zeitouni, N. and I. Milstein, "The Role of Social Support in Teachers' Intention to use ICT Tools in Their Classrooms", in Proceeding of PICMET' 17: Technology Management for Interconnected World. 2017.

[45] Schaefer, C., Coyne, and Lazarus, "The Health-Related Functions of Social Support". Journal Of Behavioral Medicine", 1981. 4: p. 381-406.

[46] Kim, H.S., D.K. Sherman, and S.E. Taylor, "Culture and Social Support". Am. Psychological, 2008. 63: pp. 518-526.

[47] Liang, et al., "What Drives Social Commerce: The Role of Social Support and Relationship Quality". International Journal of Electronic Commerce, 2011. 16(2): p. 69-90.

[48] Coulsan, N.S., "Receiving Social Support Online: An Analysis of A Computer-Mediatednsupport Group for Individuals Living with Irritable Bowel Syndrome". Cyberpsychology \& Behavior, 2004. 8: p. 580-584.

[49] Yahia, I.B., N. Al-Neama, and L. Kerbache, "Investigate the Drivers for Social Commerce in Social Mediaplatform: Importance of Trust, Social Support and the Platform Perceived Usage". Journal of Retailing and Consumer Services, 2018. 41: p. 11-19.

[50] Shanmugam, M., et al., "Measuring Continuance Participation in Online Communities". Journal of Theoretical and Applied Information Technology, 2017. 95(15): p. 3513-3522.

Formulation of an integrated social commerce framework to promote social capital... (Mohana Shanmugam) 


\section{BIOGRAPHIES OF AUTHORS}

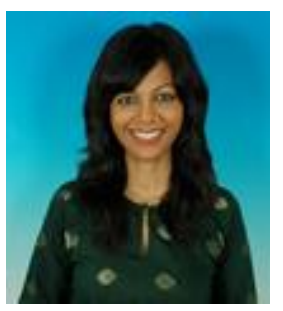

Mohana Shanmugam received her Ph.D degree in information systems from Universiti Putra Malaysia in 2017. She is a certified PSMB trainer and a senior lecturer at the Information Systems Dept, with the College of Computing and Informatics, UNITEN. She has more than 10 years of experience handling a diverse academic process caseload and over 8 years of experience as an active researcher. Her research interests include Social Commerce, IS Theories, Social Media Marketing and IS Adoption.

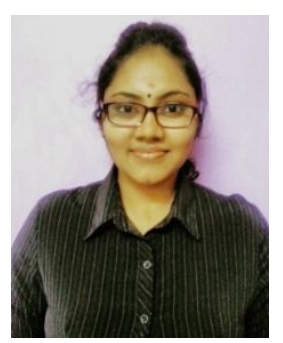

Vinitha Karunakaran received her B.Tech (Information System) (Hons.) from Universiti Tenaga Nasional in 2018. She is working as a Research Officer in Universiti Tenaga Nasional (UNITEN) under Information Systems department. Her research interests include Management Information Systems, IS theories and Knowledge Management.

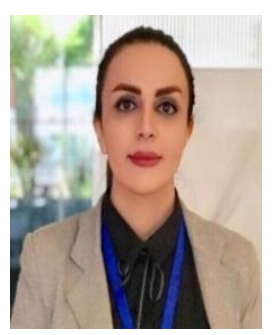

Asra Amidi received both her M.Sc. and Ph.D degree in knowledge management from Multimedia University and Universiti Putra Malaysia, in 2012 and 2018 respectively. She has been serving at the Malaysian Hospitality College as an academic staff. Her research interests include knowledge management, information systems, social media, social commerce, and Management Information Systems. 